\title{
Estimation of glycemic index of traditional paddy varieties through on farm trial (2018-2019)
}

\section{P. Karuppasamy and M.R. Latha}

Received: 19.02.2020; Revised: 06.03.2020; Accepted: 20.04.2020

See end of the paper for authors' affiliations

P. Karuppasamy

ICAR-KVK, Vamban, Pudukkottai

(T.N.) India

Email : samysks@gmail.com
ABSTRACT : The rising prevalence of diabetes is closely associated with industrialization, urbanization, socio-economic development and changes in the life style. The rice varieties namely TRY-3, Black Kavuni and Karungkuruvai were selected for the study based on their popularity, nutritional characteristics and other specific characteristics in Tamil Nadu. Initially the non-diabetic participants were screened by conducting glucose tolerance test by administering glucose powder available in the market dissolved in potable water containing $50 \mathrm{~g}$ of glucose as reference carbohydrate. For the intervention rice varieties viz., TRY-3, Black Kavuni and Karungkuruvai containing 50g of carbohydrate in the form flakes and provided to the healthy participant. The blood glucose level of the participants before administering test food and during $15^{\text {th }}, 30^{\text {th }}, 45^{\text {th }}, 60^{\text {th }}, 90^{\text {th }}$ and $120^{\text {th }}$ minutes were noted and taken for calculating the glycemic index. The Carbohydrate and crude fibre content of TRY-3, Black Kavuni and Karunkuruvai were $70.23 \mathrm{~g}$ and $0.99 \mathrm{~g}, 62.89 \mathrm{~g}$ and $1.70 \mathrm{~g}$ and $63.09 \mathrm{~g}$ and $2.01 \mathrm{~g}$, respectively. The Consumer acceptability of TRY-3 was high than Black Kavuni and Karunkuruvai with values are 8.7, 8.1 and 7.8, respectively. The recovery percentage of Black Kavuni was high than Karunkuruvai and TRY-3 with values are 58 per cent, 55.2 per cent and 53.5 per cent, respectively. In the present study the Glycemic index of black kavuni (53.10) is lesser than karunkuruvai (55.50) which are in the low Glycemic foods. TRY 3 has a G.I. of 68.20 which is higher Glycemic index than traditional varieties.

KEY WORDS: Traditional rice, Nutritional characteristics, Glycemic Index

- HOW TO CITE THIS PAPER : Karuppasamy, P. and Latha, M.R. (2020). Estimation of glycemic index of traditional paddy varieties through on farm trial (2018-2019). Asian J. Home Sci., 15 (1) : 33-37, DOI: 10.15740/HAS/AJHS/15.1/33-37. Copyright@ 2020: Hind Agri-Horticultural Society. 